\title{
CORRECTION
}

\section{Encephalitis and Myelitis in a Young Woman}

Overlap Syndrome, Thyroiditis, and Occult Tumor From the National Multiple Sclerosis Society Case Conference Proceedings

Neurol Neuroimmunol Neuroinflamm 2021;8:e1072. doi:10.1212/NXI.0000000000001072

In the Diagnostic and Treatment Challenges article "Encephalitis and Myelitis in a Young Woman: Overlap Syndrome, Thyroiditis, and Occult Tumor From the National Multiple Sclerosis Society Case Conference Proceedings" by Esfanhani et al., ${ }^{1}$ the first author's name should be "Neda Zarghami Esfahani." The authors regret the error.

\section{Reference}

1. Zarghami Esfanhani N, Wundes A, Varkey T, et al. Encephalitis and myelitis in a young woman: overlap syndrome, thyroiditis, and occult tumor from the National Multiple Sclerosis Society Case Conference proceedings. Neurol Neuroimmunol Neuroinflamm. 2021; 8(5):e1026. doi: 10.1212/NXI.0000000000001026. 


\section{Neurology \\ Neuroimmunology \& Neuroinflammation}

\section{Encephalitis and Myelitis in a Young Woman: Overlap Syndrome, Thyroiditis, and Occult Tumor From the National Multiple Sclerosis Society Case Conference Proceedings \\ Neurol Neuroimmunol Neuroinflamm 2021;8; \\ DOI 10.1212/NXI.0000000000001072}

This information is current as of August 4, 2021

Updated Information \& Services

References

Permissions \& Licensing

Reprints including high resolution figures, can be found at:

http://nn.neurology.org/content/8/5/e1072.full.html

This article cites 1 articles, 1 of which you can access for free at: http://nn.neurology.org/content/8/5/e1072.full.html\#\#ref-list-1

Information about reproducing this article in parts (figures,tables) or in its entirety can be found online at:

http://nn.neurology.org/misc/about.xhtml\#permissions

Information about ordering reprints can be found online: http://nn.neurology.org/misc/addir.xhtml\#reprintsus

Neurol Neuroimmunol Neuroinflamm is an official journal of the American Academy of Neurology.

Published since April 2014, it is an open-access, online-only, continuous publication journal. Copyright $\odot$ 2021 American Academy of Neurology. All rights reserved. Online ISSN: 2332-7812.

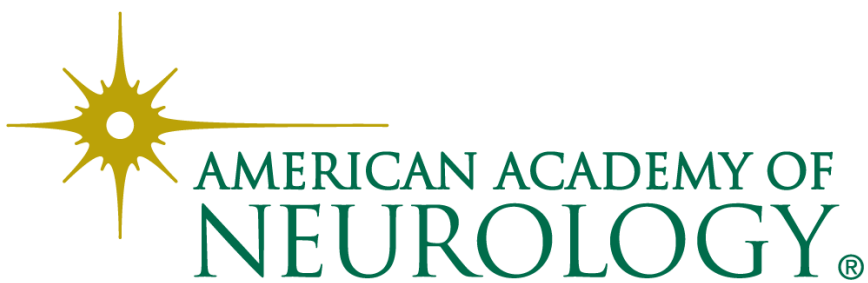

